\title{
Editorial: Think
}

Philosophy is now in its 77 th year. It likes to think of itself as still sprightly in approach and open-minded in content. Nevertheless it has a burden of history and of expectation, and it has an academic level to maintain. Even though it strives, as always and unlike some of its contemporaries, to be written for the most part in a language recognizable as English and to address topics of genuine human interest, its reputation defends on its being recognized as a leading journal of philosophy in the academic world.

So it is a pleasure to welcome, in April 2002, a sister periodical, called simply Think*. Like Philosophy, Think will be published under the auspices of the Royal Institute of Philosophy. It will do some of the educational things the Royal Institute of Philosophy was originally set up to do, but cannot be done in an academic journal such as Philosophy. Think will consist, for the most part, of short articles of genuine philosophy, but they will be articles accessible to any who are prepared simply to think. In particular, Think will aim to interest young people, including the increasing numbers who now take philosophy as part of the school curriculum, but who may have little or no knowledge of academic philosophy.

Think is not a magazine. Its pages will not contain philosophical gossip or anecdote. These are not unworthy activities, even in a philosophical context, but there are other places for them. Even where imaginative in presentation, and even though they need not have the originality and depth expected in an academic journal, the articles in Think will be recognizably philosophical in tone and ambition. Think's articles will aim, simply, to make their readers think philosophically, in the best possible way, and to think about topics which are recognizably philosophical.

Not that Think will eschew controversy. Its authors will, from time to time, defend controversial positions, and will provoke

* Note: The first issue of Think is published in April 2002, and features contributions from Michael Clark, Richard Dawkins, Richard Swinburne, Mary Warnock and others. Subscriptions for individuals cost $£ 15$ per year in the UK (three issues) and can be taken out by calling 01422-879097 during normal office hours. It is also possible to subscribe online on Think's website (www.royalinstitutephilosophy.org/think), where information is also given on overseas and institutional prices. 


\section{Editorial}

equally controversially replies. And if at times the opinions expressed in Think have a younger or more radical feel to them than those characteristically expressed in its older and more venerable relation, that is as it should be, and all a proper part of the role of the Royal Institute of Philosophy. 